\title{
Refugees' perceptions regarding HIV and AIDS in Ba-Phalaborwa Municipality in Limpopo Province
}

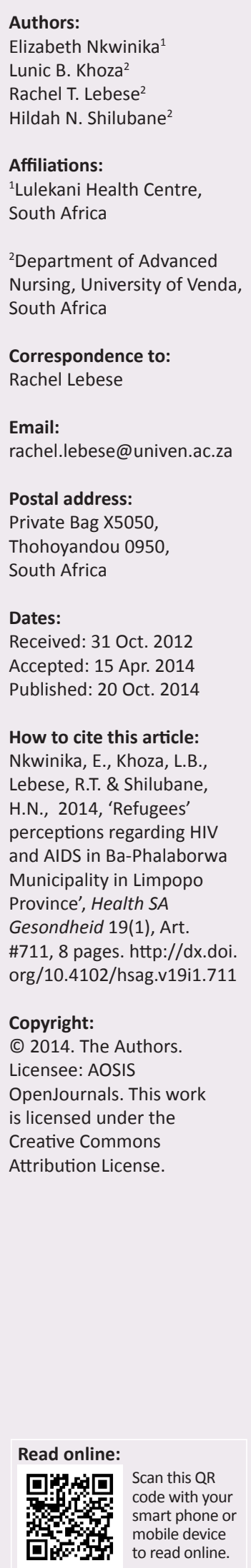

Background: Human Immunodeficiency Virus and Acquired Immune Deficiency Syndrome (HIV and AIDS) remain a serious threat to population health and economic well-being of individuals in conflict societies. Sub-Saharan Africa (SSA) is overwhelmingly affected by HIV and is the region with the highest number of armed conflicts worldwide.

Aim: The research aimed at exploring and describing the perceptions of the refugees at Humulani Village in Ba-Phalaborwa municipality, Limpopo province, about HIV and AIDS.

Objectives: The objectives included determining the gender perceptions about HIV and AIDS and also providing recommendations for ways to increase the refugees understanding of this disease.

Methods: The approach used for the research was quantitative. The target population of the study was all the refugees at Humulani Village. The sample comprised both men $(n=78)$ and women $(n=122)$ who participated by completing questionnaires. The sample of the refugees consisted of different ethnic groups from Mozambique, Nigeria, Ghana and Zimbabwe. The questionnaire consisted of two sections, section A contained the biographic data and section B interrogated the refugees' knowledge of HIV.

Results: The findings of the study revealed that the participants had low levels of knowledge regarding HIV which could be attributed to their believing the myths about HIV and AIDS.

Conclusion: The HIV-infected refugee population in Limpopo may continue to grow unless the unique needs of the refugees, such as strengthening the reproductive health services, maternal and child care and family planning, improving the educational and socio-economic status, are not addressed.

Agtergrond: Menslike immuniteitsgebrekvirus (MIV) en verworwe immuniteitsgebreksindroom (vigs) bly 'n ernstige bedreiging vir die gesondheid van die bevolking, asook die ekonomiese welstand van individue in konflik-samelewings. Sub-Sahara Afrika (SSA) word oorweldigend deur MIV geraak en is die streek met die hoogste aantal gewapende konflikte wêreldwyd.

Doelwitte: Die navorsing het ten doel gehad om vlugtelinge te Humulani dorpie in BaPhalaborwa munisipaliteit, Limpopo provinsie, se persepsies oor MIV en vigs te ondersoek en beskryf. Die doelwitte het die bepaling van geslagspersepsies oor MIV en vigs ingesluit, asook om aanbevelings te bied vir maniere om die vlugtelinge ' $n$ beter begrip van MIV en vigs te gee.

Metode: ' $n$ Kwantitatiewe benadering tot hierdie navorsing is gevolg. Die teikenpopulasie van die studie was al die vlugtelinge te Humulani dorpie. Die steekproef het uit beide manlike $(n=78)$ en vroulike $(n=122)$ deelnemers bestaan wat vraelyste voltooi het. Die steekproef vlugtelinge was van verskillende etniese groepe afkomstig: Mosambiek, Nigerië, Ghana en Zimbabwe. Die vraelys het twee afdelings gehad: Afdeling A het die biografiese data bevat en Afdeling B het die vlugtelinge se kennis van MIV ondersoek.

Resultate: Die bevindinge van die studie het onthul dat die deelnemers oor lae kennisvlakke rakende MIV beskik - dit kan toegeskryf word aan hul geloof in die mites aangaande MIV en vigs.

Gevolgtrekking: Die populasie van MIV-besmette vlugtelinge in Limpopo mag steeds groei indien daar nie aandag geskenk word aan die unieke behoeftes van die vlugtelinge nie, soos die versterking van voortplantingsgesondheidsdienste, gesinsbeplanning, en moeder- en kindersorg, asook die verbetering van hul opvoedkundige en sosio-ekonomiese welstand. 


\section{Introduction Background}

HIV remains a serious threat to both population health and the economic wellbeing of individuals in conflict societies (Mills et al. 2006). There is a geographic overlap between HIV and sexually-transmitted infections (STIs) in a refugee population. The United Nations High Commission for Refugees (UNHCR) indicates that there are approximately 42 million people worldwide who are displaced from their homelands, 'equivalent to one out of every 170 people' globally (UNHCR 2008). This situation results in refugees experiencing difficult living conditions which are characterised by poor nutrition, poverty, overcrowding and no discernible healthcare. These factors are thought to increase the risk for HIV infection, which can be attributed to refugees having limited knowledge regarding transmission of HIV and methods of prevention (Beckwith et al. 2009). The strategies designed to prevent the spread of HIV amongst refugees have been aimed specifically at altering the behaviour of individuals, but failed to take into account the societal and contextual factors that determine vulnerability (Beckwith et al. 2009). Tanaka et al. (2008) indicate that few publications 'have highlighted factors associated with HIV risk in refugee operations'. Various studies have further denounced the absence of reproductive health services for these populations, particularly the women and children (Austin et al. 2008; Beckwith et al. 2009; UNHCR 2008).

According to the Joint United Nations Programme on HIV / AIDS (UNAIDS) (2010), it is estimated that 34 million people are living with HIV worldwide and that 1.8 million died from complications associated with acquired immune deficiency syndrome (AIDS) in 2010. It is also estimated that one in five HIV-infected people in the world do not know that they are HIV positive (Centers for Disease Control and Prevention 2013). As at 2011, sub-Saharan Africa was the most affected region worldwide (22.9 million cases), 'with nearly 1 in every 20 adults (4.9\%) living with HIV and accounting for $69 \%$ of the people living with HIV worldwide' (UNAIDS 2012). The southern Africa sub-region 'continues to experience the most severe HIV epidemic in the world. One third (34\%) of all people living with HIV globally in 2009 resided in the 10 countries in Southern Africa, while epidemics in eastern Africa began declining about a decade ago and have since stabilised in many countries' (UNAIDS 2010). This region also has the highest number of armed conflicts worldwide and high rate of HIV amongst soldiers poses a serious threat to civilians (Ngatu \& Kanbara 2014). It is important for health professionals working in South Africa to understand the communities' beliefs about health and sickness, incorporating these beliefs into HIV programmes.

In 2010, there were approximately 1.9 million new HIV infections in sub-Saharan Africa and an estimated 11.1 million people were living with HIV in southern Africa in 2009 (UNAIDS 2010). South Africa is one of the most severely-affected countries with an HIV prevalence of $15.6 \%$ in 2002 amongst adults aged 15-49 years (Shisana 2002); this number increased to $24 \%$ in 2010 . The authors further mentioned that South Africa has the largest number of people living with HIV and AIDS in the world; approximately $10 \%$ of South Africans have progressed to AIDS. It is expected to have a great impact on the lives of South African citizens, as well as refugees who have settled in South Africa. Molefe estimated that, by the year 2010, HIV would result in approximately 380000 deaths a year (Molefe 2004).

Data regarding HIV prevalence in refugee situations are scarce. It is believed that refugees and other displaced populations are at risk of contracting the virus during and after displacement, because of the disruption to their family and/or social networks and health services, increased sexual violence and poverty, as well as the forcing of women and girls into transactional sex for money, food or protection. The deprivation experienced by displaced populations provides fertile ground for the spread of HIV and other infectious diseases (Tafuri et al. 2010; Tanaka et al. 2008).

Similar situation is reported by Beckwith et al. (2009) that ' $[t]$ here is little data on ARV utilization and outcomes for infected refugees'. By contrast, Busza et al. (2012) and UNHCR (2010a) demonstrated that the community-based programmes have been developed for pregnant refugee women living with HIV to improve access of mother-to-child transmission services. Furthermore, 'HIV prevention campaigns, condom promotion and distribution, programs addressing genderbased violence, HIV testing and counseling, the prevention of mother-to-child transmission and anti-retroviral therapy have all been implemented in various refugee settings, reaching large proportions of those in need in some instances' (UNHCR n.d.).

Tanaka et al. (2008) demonstrated that little is known about the risks and risk behaviours of refugees living in postemergency phase camps in Africa where there is continued displacement, with a lack of food and basic necessities because of limited aid from international donors which may further expose them to HIV. The aim of the study was thus to elicit the perceptions of refugees regarding HIV and AIDS.

\section{Research problem}

The motivation for this study came from the alarming statistics of HIV and AIDS in Ba-Phalaborwa subdistrict, especially the great increase in HIV and AIDS statistics amongst refugees at Humulani Village as compared with other settlements occupied by South Africans (Palabora Mining Company Limited n.d.). Despite efforts on the part of primary healthcare (PHC) nurses and workers to educate the community about $\mathrm{HIV}$, it was thus uncertain how these efforts impact on the refugees' understanding and behaviour about HIV. Statistics regarding HIV at Humulani refugee village increased by $65 \%$, whilst statistics at other settlements increased by $30 \%$ in 2003 (Palabora Mining Company Limited n.d.). In 2009, the Humulani clinic's October statistics revealed that out of 1460 clients who received voluntary counselling and testing 
(VCT), 57\% $(n=832)$ of those tested were newly diagnosed and the highest percentage of those testing positive were women $(39 \%)$ as compared with 32\% HIV-positive women in 2005. The increase in the Ba-Phalaborwa HIV statistics occurred despite road shows informing refugees about HIV in the village and schools conducted by primary healthcare nurses in Humulani.

\section{Research objectives}

The objectives of this study were:

- to describe the refugees' perception of HIV and AIDS at Humulani Village

- to determine by gender the perceptions of HIV and AIDS at Humulani Village.

\section{Definition of key concepts Refugees}

According to the Department of Home Affairs (2013), refugees 'are people who have been forced to leave their country of origin for various reasons (for example, war, violent political unrest or genocide)'. In this study, this term refers to people who fled their country and settled at Humulani Village.

\section{Perception}

Perception refers to the way in which something is understood or interpreted (The Reader's Digest 1993). In this study, perception refers to refugees' points of view with regard to HIV and AIDS.

\section{Research method and design Design}

A descriptive design was used to identify and describe the refugees' perceptions of HIV and AIDS. Descriptive research also provides an accurate profile of a group (De Vos 2003; De Vos et al. 2011). Descriptive research also presents basic background information on the study. The study gave a numerical picture of the results as the responses given by participants on the questionnaires were scored and tables were developed from these scores (De Vos 2003; De Vos et al. 2011).

\section{Data collection method}

The study was conducted at Humulani Village, which is situated in the Ba-Phalaborwa Municipality of Mopani District, an area largely inhabited by refugees. It is a rural area which was established as an informal settlement in 1986. It is $20 \mathrm{~km}$ from Lulekani Health Centre and $43 \mathrm{~km}$ from PhutaMalatji hospital. The reason for choosing Humulani Village was that it accommodated the largest number of refugees as compared with other settlements. The population studied comprised all the refugees at Humulani Village $(N=5867)$ (Department of Water Affairs and Forestry 2009). Most of the Humulani Village people were unemployed and illiterate; and the refugees originated from other African countries. The average number of children per household was seven.
Most of them started giving birth at the age of 15 and stopped giving birth between the ages of 50 and 55 (Nkwinika 2006).

A non-probability purposive sampling method was used. Purposive sampling was chosen as it is based entirely on the judgement of the researchers and is composed of elements that contain typical attributes of the refugee population. Only those refugees who could communicate in Xitsonga and volunteered their participation were included in the sample. The sample consisted of women who had already mothered children, as well as men. Initially, a target of 1000 participants was preferred for the study; however, only 200 participants were enrolled as the clinic has a low daily turnout of around 45-60 patients. It should be noted that the study could not be conducted at the Health Centre because the refugees would have had to travel long distances to get there.

Data from 200 participants were collected through the use of a questionnaire, which was administered during working hours at Humulani clinic. As most of the refugees were illiterate, the researchers read the questions to them (translated from English to Xitsonga) and their responses were recorded on the questionnaire. All participants answered verbally. The study was conducted over a period of 10 weeks. It did not interfere with the normal routine of the clinic as the questionnaires were administered to participants who were waiting to see the doctor or nurse.

The questionnaire consisted of a list of 45 questions assessing HIV knowledge. The questions were closed-ended, with valid responses being 'true', 'false' or 'don't know'. However, clarification was offered to the participants when needed. Answers were recorded by placing a tick in the space provided below the answer of their choice. The questionnaire was developed in English and translated into Xitsonga. It was then pre-tested amongst refugees with a similar background to the study participants in order to ensure cognitive appropriateness, as well as construct and face validity. As a result of the pilot test, the questionnaire was revised into English and then back-translated into Xitsonga by an academician proficient in the language.

The setting for the research measurements was controlled as the research was conducted in a clinic where people came for consultation (De Vos et al. 2011).

\section{Data analysis}

The data were analysed statistically using IBMSPSS Statistics for Windows, version 21.0 (IBM Corp., Armonk, NY 2012). The results, after analysis using SPSS, are presented under 'biographical information' and 'knowledge regarding HIV / AIDS'.

\section{Validity and reliability}

Reliability was ensured by minimising sources of measurement error such as data collector bias where the researcher was the only one to administer the questionnaire, 
which ensured that questions were clarified in the same manner. Content validity was guaranteed by ensuring consistency in the administration of the questionnaire.

\section{Ethical considerations}

Permission to conduct the study was obtained from the provincial Department of Health and Social Development of Limpopo. The participants' rights, interests and wishes were considered first when choices were made regarding reporting the data. Anonymity and confidentiality were assured.

The participants were informed that participation was voluntary and that confidentiality of their information would be ensured. The participants were assured that their responses would not be linked to their personal identities. Consent was obtained from all participants in the study prior to administering the interview questionnaire, which was done in a private room. The participants were assured that they had the right to refuse to participate in the study without any penalty and also to withdraw from the study at any time.

\section{Results}

A total of 200 questionnaires was completed. Data were analysed as discussed below.

\section{Biographical data}

The majority of the participants $(29 \% ; n=57)$ fell between the ages of 26 and 30 years, followed by $28 \%(n=55)$ who were between 15 and 25 years of age. The clinic is mostly used by younger people; and this can be further argued against the problem statement that the increased statistics of HIV and AIDS at Humulani Village at $65 \%$ affect the young adults more than older people.

The sample consisted of more women $(61 \% ; n=122)$ than men $(39 \% ; n=78)$. This could be because women in African cultures bring children to the clinic for consultation, along with the fact that men may be less responsible with regard to seeking medical health than women.

The majority of participants were Mozambicans (43\%; $n=86)$ followed by Zimbabweans $(28 \% ; n=55)$. This could be because both the Mozambican and Zimbabwean people can cross the border on foot and reach Humulani Village easily. The high percentage of Mozambicans might be a result of the fact that their home language is Xitsonga, thus making it easy for them to be included in the study.

\section{Refugees' knowledge regarding the study topic ( $n=200)$}

In the analysis, the study considered responses of $50 \%$ and above to denote sufficient knowledge (True; False; and Do not know). In addition, the discussion covers only findings that were perceived by the researchers to have impact on the extent of the refugees' knowledge regarding HIV. All questions covered can be found in Table 1.

Only women can spread HIV to men: The overwhelming majority of participants $(98 \% ; n=196)$ perceived that only women can spread HIV to men, whilst only $2 \%(n=4)$ of the participants disagreed. The participants who were interviewed during the completion of questionnaires were questioned further regarding why only women could spread HIV to men. Some participants indicated that only women are sex workers and that the attire they wear entices men to have sex with them. This demonstrate the participants' lack of knowledge about HIV and the mode of transmission. Long and Ankrah (2000) stressed that when men die of HIV and HIV-related disease, women are accused of having caused the death.

Promiscuity is the only driving force behind the HIV epidemic: Of the participants, $94 \%(n=187)$ indicated that they believed that promiscuity was the only driving force behind the HIV epidemic, whilst only $6 \%(n=13)$ indicated that this was not the case. The participants who were interviewed during the completion of the questionnaires were asked for clarification regarding why promiscuity was the driving force behind the epidemic; they responded that only people who slept around got HIV. These findings were supported by Long and Ankrah (2000), who demonstrated that the most common mode of transmission of HIV throughout the world is by sexual intercourse - whether oral, anal or vaginal is unimportant. In the developing world, HIV is spread largely through heterosexual intercourse and $85 \%$ of such transmission is outside of marriage (i.e., through promiscuity or sex before marriage and infidelity in marriage).

Only men can spread HIV: Ninety-two per cent $(n=183)$ of the participants indicated that only men could spread HIV; and only $9 \%(n=17)$ indicated that this was not so. This finding showed that the participants associated HIV with sex. This way of thinking persisted, despite HIV awareness that were held in the area, hosted by the district and provincial government at Humulani refugees' village in 16 April 2006, before data collection was done. According to Manzardo et al. (2008), the prevalence of HIV infection is different across groups of immigrants.

A pregnant woman can give AIDS to her baby: The majority of participants $(84 \% ; n=168)$, indicated that a pregnant woman could transmit AIDS to her baby, $12 \%(n=23)$ mentioned that this was not the case and 5\% $(n=9)$ said they did not know. This finding could imply that participants had little knowledge about the differentiation between HIV and AIDS. Van Dyk (2008) stated that AIDS is a collection of many conditions that manifest in the body because of HIV, a virus that weakens the body's immune system so that it can no longer fight the disease-causing agents that invade the body. During interviews, the researcher asked the participants if they ever been present in one of the HIV and AIDS health programmes hosted by primary healthcare workers in their 
TABLE 1: Assessment of refugees' knowledge $(N=200)$.

\begin{tabular}{|c|c|c|c|c|c|c|}
\hline \multirow[t]{2}{*}{ Knowledge assessment items } & \multicolumn{2}{|c|}{ True } & \multicolumn{2}{|c|}{ False } & \multicolumn{2}{|c|}{ Do not know } \\
\hline & $n$ & $\%$ & $n$ & $\%$ & $n$ & $\%$ \\
\hline 1. Only women can spread HIV to men* & 196 & 98 & 4 & 2 & 0 & 0 \\
\hline 2. Promiscuity is the only driving force behind the HIV epidemic * & 187 & 93.5 & 13 & 6.6 & 0 & 0 \\
\hline 3. Weight loss is sure an indication/symptom of HIV & 186 & 93 & 11 & 5.5 & 3 & 1.5 \\
\hline 4. Only men can spread HIV * & 183 & 91.5 & 17 & 8.5 & 0 & 0 \\
\hline 5. HIV has spread so far that prevention efforts are irrelevant & 183 & 91.5 & 10 & 5 & 7 & 3.5 \\
\hline 6. AIDS is a homosexual disease & 179 & 89 & 20 & 10 & 1 & 0.5 \\
\hline $\begin{array}{l}\text { 7. One can only contact HIV by having repeated sexual intercourse with an HIV-positive } \\
\text { or AIDS patient }\end{array}$ & 177 & 88.5 & 19 & 9.5 & 4 & 2 \\
\hline 8. AIDS is a disease of gay white men in South Africa & 173 & 86.5 & 20 & 10 & 7 & 3.5 \\
\hline 9. A pregnant women can give AIDS to her baby * & 168 & 84 & 23 & 11 & 9 & 4.5 \\
\hline $\begin{array}{l}\text { 10. Someone who is infected with HIV but does not yet have full-blown AIDS can } \\
\text { transfer HIV through sexual contact * }\end{array}$ & 18 & 9 & 166 & 83 & 16 & 8 \\
\hline 11. HIV can be transmitted through mosquitoes & 165 & 82.5 & 15 & 7.5 & 20 & 10 \\
\hline 12. A mother can transmit HIV to her child through breast-feeding * & 35 & 17.5 & 163 & 81.5 & 2 & 1 \\
\hline 14. There is a cure for AIDS & 158 & 79 & 17 & 8.5 & 25 & 12.5 \\
\hline 15. When both partners are HIV positive, they do not need to use a condom * & 153 & 76.5 & 46 & 23 & 1 & 0.5 \\
\hline 16. HIV is the disease of the poor & 153 & 76.5 & 20 & 10 & 7 & 3.5 \\
\hline 17. People with HIV generally develop AIDS as a result of other diseases* & 14 & 7 & 152 & 76 & 34 & 17 \\
\hline 18. A person cannot get virus from someone with the AIDS Virus [sic] & 52 & 26 & 137 & 68.5 & 11 & 5.5 \\
\hline 19. HIV can be transmitted through semen * & 31 & 20.5 & 136 & 68.5 & 23 & 11.5 \\
\hline 20. Someone who looks healthy can be infected by HIV * & 48 & 24 & 133 & 66.5 & 19 & 9.5 \\
\hline 21. HIV can be present in vaginal fluid & 28 & 14 & 132 & 66 & 40 & 20 \\
\hline 22. AIDS is caused by HIV & 40 & 20 & 130 & 65 & 30 & 15 \\
\hline 23. Someone infected with HIV gets AIDS within three months & 130 & 65 & 40 & 20 & 30 & 15 \\
\hline 24.A person can have HIV for seven years or more without having symptoms & 57 & 28.5 & 123 & 61.5 & 20 & 10 \\
\hline 25.You are likely to get HIV if your sexual partner has had sex with a lot of people * & 23 & 11.5 & 107 & 53.5 & 70 & 35 \\
\hline 26.HIV can be transmitted through anal sex & 41 & 20.5 & 96 & 48 & 63 & 31.5 \\
\hline 29. The use of condoms greatly reduces the risk of HIV transmission* & 31 & 15.5 & 78 & 39 & 91 & 45.5 \\
\hline 30. HIV is the virus that causes AIDS & 52 & 26 & 61 & 30 & 87 & 43.5 \\
\hline
\end{tabular}

Note: *, Only findings that were perceived by the researchers to have an impact on the extent of the refugees' knowledge regarding HIV were discussed.

HIV, human immunodeficiency virus; AIDS, acquired immune deficiency syndrome; TB, tuberculosis.

area. The majority $(n=168)$ of participants indicated that they had never attended such health programme. According to Peltzer, Vallière and Tabanes (2011), 'prevention programmes aimed at the most at risk groups of HIV infection have not been very efficient in reaching [this population]. Where such prevention programmes were available, unsatisfactory results were achieved'.

Someone who is infected with HIV but does not yet have full-blown AIDS can transfer HIV through sexual contact: The majority of the respondents $(83 \% ; n=166)$ indicated that someone who was infected with HIV but did not yet have full-blown AIDS could not transfer HIV through sexual contact; $9 \%(n=18)$ said, correctly, that this was not the case; and $8 \%(n=16)$ said they did not know. This finding showed that the respondents lacked knowledge regarding the fact that a person can transmit HIV during all stages of their HIV infection. These findings are supported by Tanaka et al. (2008) who demonstrated that 5.4\% (61/1140) of the refugees they surveyed who had never heard of HIV and/or AIDS, the majority (52/61) were women. This finding could imply that the respondents think that they do not have to protect themselves against re-infection, whilst new infection can cause an increase in the viral load in the blood. This reveals the need to strengthen HIV education efforts, particularly amongst women.

A mother can transmit HIV to her child through breastfeeding: Eighty-two per cent $(n=164)$ of the participants indicated that a mother could not transmit HIV to her child through breast-feeding, whilst $18 \%(n=35)$ believed that she could and $1 \%(n=2)$ said that they did not know. This finding shows that the majority of the participants do not know that HIV is present in breast-milk and that the mother can transmit it to her newborn during breast feeding if precautions are not taken. This is supported by Coovadia et al. (2007), who mentioned that there is an apparent 'protective effect' when an HIV-infected mother breastfeeds her infant exclusively for the first three months of life. Kourtis et al. (2013) demonstrated that 'disruption in intestinal integrity is a mechanism of HIV transmission to infants through breast-feeding'. Furthermore, Slater, Stringer and Stringer (2010) maintain that most of women in rural and remote areas in Africa are expected by cultural norms to breast-feed their infants, thereby risking transmitting the virus through breast-milk.

If a woman falls pregnant whilst she is HIV positive, the child that she will give birth to is obviously going to be 
HIV positive: Eighty per cent $(n=160)$ of the participants indicated that if a woman fell pregnant whilst she was HIV positive, the child that she would give birth to would obviously be HIV positive. Fifteen per cent $(n=30)$ indicated that the child would not necessarily be HIV positive, whilst $5 \%(n=10)$ said that they did not know. The findings would imply that the participants do not know that during pregnancy, namely, whilst the foetus is still in utero, the placental membranes act as a barrier against harmful agents and maternal erythrocytes are too large to pass through the placenta. According to Myles (2000), however, there is still a chance that child can be infected with HIV, as the virus is able to pass through the placental barrier. Van Dyk (2008) mentioned that the mother is more likely to transmit the virus to her foetus during pregnancy if she becomes infected just before or during pregnancy, or if she has an HIV-related illness or full-blown AIDS. The reason for this is that the mother is more infectious at those phases of the disease, because the HIV viral load is usually high and the CD4 cell count is low during both seroconversion and when the individual is ill with AIDS.

People with HIV generally develop AIDS as a result of other diseases: An overwhelming majority 76\% $(n=152)$ indicated, incorrectly, that people with HIV generally did not develop AIDS as a result of other diseases; $17 \%(n=34)$ said they did not know; and only 7\% $(n=14)$ were correct in saying that people with HIV generally develop AIDS as a result of other diseases.

HIV can be transmitted through semen: Sixty-nine per cent $(n=138)$ of the participants mentioned that HIV could not be transmitted through semen and 12\% $(n=23)$ said they did not know. This finding showed poor knowledge regarding the mode of transmission of HIV, so that when sex then takes place without a condom, it results in a high risk of HIV transmission. Tafuri et al. (2010) demonstrated that refugee populations are more at risk of contracting HIV and STDs because of a lack of information with regard to STD prevention being provided to the migrant communities in the host country. Tanaka et al. (2008), however, stated that most refugees amongst Congolese want to have many children. Making many children, in their culture, creates power as children are considered a source of labour and this understanding support the findings of the study.

Someone who looks healthy can be infected with HIV: Sixty-seven per cent $(n=52)$ of the participants mentioned that someone who looks healthy could not be infected by HIV, $24 \%(n=48)$ said that a healthy-looking person can be infected by HIV, whilst $10 \%(n=19)$ said they did not know. The majority of participants showed poor knowledge of the stages of HIV and believed that the person can live for long without evidence of any signs and symptoms. This was a persistent belief, despite HIV and AIDS awareness education hosted by the districts and provincial government at Humulani refugees' village in April 2006. 'The belief that a healthy-looking person cannot be infected with HIV is a common misconception that can result in unprotected sexual intercourse with infected partners' (UNAIDS 2014).
You are likely to get HIV if your sexual partner has had sex with a lot of people: Fifty-three per cent $(n=106)$ of the participants indicated that you were not likely to contract HIV if your sexual partner has had sex with a lot of people; $35 \%(n=70)$ said they did not know; and only $12 \%$ $(n=23)$ indicated that you were likely to contract HIV in this scenario. The participants indicated that sleeping around was the only way of transmitting HIV to others. This finding confirmed the participants' poor knowledge with regard to HIV transmission. Based on the Chi-square statistics it was found that there was significant difference in the knowledge of HIV transmission between men and women $\left(X^{2}=11.05\right.$ and $p<0.5)$, with women being significantly more knowledgeable than men. This is supported by UNAIDS (2012), which stated that females seek medical help than men and that ' $[g]$ ender norms also increase men's vulnerability to HIV, encouraging high risk behavior and deterring them from seeking sexual health services or acknowledging their lack of knowledge about HIV'.

When both partners are HIV positive, they don't need to use a condom and the use of a condom greatly reduces the risk of HIV transmission: These two items are discussed simultaneously due to their relatedness. Seventy-seven per cent $(n=142)$ of the participants mentioned that when both partners were HIV positive, there was no need to use condoms; $23 \%(n=46)$ said that condom use was still necessary; whilst $1 \%(n=2)$ said that did not know. Forty-five per cent $(n=82)$ of the respondents stated that they did not know whether the use of condoms gave effective protection. Thirty-nine per cent $(n=78)$ of the participants indicated that the use of condoms did not give effective protection, as opposed to $16 \%(n=31)$, who felt that it did. The findings could imply that the participants had a negative attitude about the need to use a condom and that they did not know the degree to which someone who is HIV positive can become re-infected, thus causing a possible more rapid progression to AIDS. This lack of information was criticised because there had been a great amount of awareness raised by the 'Love Life' team in this area, during which they demonstrated the proper use of condoms and also ensured the availability of condoms in public spaces such as shopping malls, public toilets, shebeens and taverns. In their study, Tanaka et al. (2008) concluded that refugees were reluctant to use condoms because they wanted more children 'in order to get more food through additional ration cards'. Food rationing is calculated based on the number of family members who need it.

\section{Discussion}

The overall knowledge discovered in the current study could be considered to be poor or at a fairly low level. This judgement is based on the researchers' decision to use the acceptable $50 \%$ 'correct responses' as an indication of good levels of knowledge, as established in a test sample of rural participants. The study conducted by Tanaka et al. (2008) on Congolese refugees in Tanzania had shown an interesting finding in that the large percentage of refugees $(63 \%-93 \%)$ who had heard of HIV and / or AIDS 
demonstrated a high level of knowledge and positive attitudes toward HIV and its prevention.

There are several crucial items not discussed in this article, namely, those scoring below the expected percentage of $50 \%$. These low scores are a sign of lack of knowledge with regard to HIV and AIDS. A study by Steele, Richmond-Reese and Lomax (2006) indicated that white participants consistently performed better than black participants with regard to HIV and AIDS knowledge. Later studies by Beckwith et al. (2009) and MacLeod-Bluver (2009) elucidated the fact that the lower level of knowledge for black participants may, however, be an effect of their socio-economic status, involving issues such as poverty, migrant labour, the low status of women, stigma, discrimination, literacy levels and the lack of formal education, rather than ethnicity.

The findings in this study imply that participants have a poor level of knowledge with regard to HIV and AIDS and were unable to differentiate between the two terms. It appears that the participants hold negative attitudes toward the use of condoms and they also discriminate against those who are HIV positive, despite expecting them to disclose their HIV status. The participants did not know that opportunistic infections such as tuberculosis can lower the immune system's response and predispose the HIV-positive individual to a more rapid onset of AIDS. The research conducted by Family Health International (2000) revealed that women do not have control over their sex life; traditional society expects them to do what their husbands tell them. Furthermore, Tompkins et al. (2006) demonstrated that a significant proportion of refugees are poorly educated about HIV infection, exhibiting attitudes and beliefs that may increase their risk of disease acquisition, thus creating barriers to HIV prevention and care, leading them to engage in high-risk sexual behaviour.

\section{Limitations of the study}

In this study, non-probability sampling was used to identify the participating village; and the sample was only representative of the population of refugees at Humulani Village in South Africa. This implies that the results might not be generalisable to all refugees in South Africa.

\section{Recommendations}

Based on the results of this study, the following recommendations could begin to address some of the perceptions that contribute to refugees' lack of HIV and AIDS knowledge at Humulani Village in Limpopo Province, South Africa. Tanaka et al. (2008) assert that the promotion of positive changes in refugee behaviour is a complex process, requiring an understanding of their vulnerability, risk environment and behaviour.

It is recommended that the efficacy of the different types of HIV and AIDS programmes be assessed before they are implemented. Repeated exposure to information involving video or film presentations, skill-based training, role plays and peer education have proved to be more effective in changing attitudes than once-off, formal education programmes. Furthermore, the future HIV and AIDS education programmes and awareness campaigns need to adopt strategies that target specific groups of people in order to be more effective.

\section{Conclusion}

The HIV-infected refugee population in Limpopo may continue to grow if the unique needs of the refugees are not given attention. These needs include: strengthening the reproductive health services; offering maternal and child care and family planning; and instituting measures aimed at improving the educational and socioeconomic status of the refugees. Our study, therefore, suggests that healthcare workers, in collaboration with the Ba-Phalaborwa municipality, be encouraged to form supportive peer educator groups which will participate actively in the awareness education in the municipality, whilst organising peer meetings to discuss the effectiveness and efficiency of their activities.

\section{Acknowledgements}

This article is based on research done for a Master's thesis by the first author: 'Refugees' perception of HIV and AIDS in Ba-Phalaborwa Municipality, Limpopo Province', submitted to the Turfloop Graduate School of Leadership and Management Sciences, University of Limpopo, Polokwane, in partial fulfilment of the requirement for a Master's Degree in Development.

The researchers would like to acknowledge the voluntary participation of refugees in the study. The researchers would also like to thank their employer, the University of Venda, for giving them time to conduct the study.

\section{Competing interests}

The authors declare that they have no financial or personal relationship(s) which may have inappropriately influenced them in writing this article.

\section{Authors' contributions}

E.N. (Lulekani Health Centre) was the project leader and was responsible for data collection; L.B.K. (University of Venda) was the project supervisor and conceptualised the research project; R.T.L. (University of Venda) wrote the manuscript and participated in the data analysis; and H.N.S. (University of Venda) performed the literature review and participated in the data analysis.

\section{References}

Austin, J., Guy, S., Lee-Jones, L., McGinn, T. \& Schlecht, J., 2008, 'Reproductive health A right for refugees and internally displaced persons', Reproductive Health Matters 16(31), 10-21. http://dx.doi.org/10.1016/S0968-8080(08)31351-2

Beckwith, C.G., DeLong, A.K., Desjardins, S.F., Gillani, F., Bazerman, L., Mitty, J.A. et al., 2009, 'HIV infection in refugees: A case-control analysis of refugees in Rhode Island', International Journal of Infectious Diseases 13(2),186-192. http:// dx.doi.org/10.1016/j.ijid.2008.06.004 
Busza, J., Walker, D., Hairston, A., Gable, A., Pitter, C., Lee, S. et al., 2012 'Community-based approaches for prevention of mother to child transmission in resource-poor settings: A social ecological review', Journal of the International AIDS Society 15(Suppl 2), 17373. http://dx.doi.org/10.7448/IAS.15.4.17373

Coovadia, H.M., Rollins, N.C., Bland, R.M., Little, K., Coutsoudis, A., Bennish, M.L. et al., 2007, 'Mother-to-child transmission of HIV-1 infection during exclusive breastfeeding in the first 6 months of life: An intervention cohort study', The Lancet $60283-9$

Department of Home Affairs, 2013, Refugee status \& asylum, viewed 17 July 2014, from http://www.home-affairs.gov.za/index.php/refugee-status-asylum

Department of Water Affairs and Forestry, 2009, Water Services Information Reference Framework: Water and sanitation backlog eradication status report, Department of Water Affairs, Directorate: Water Services Macro Planning and Information Systems, Limpopo.

De Vos, A.S., 2003, Researchers at grass roots for the social sciences, Van Schaik, Pretoria.

De Vos, A.S., Strydom, H., Fouché, C.B. \& Delport, C.S.L., 2011, Research at grass roots: For the Social Sciences and Human Service professions, 4th edn., Van Schaik, Pretoria.

Ebeniro, C.D., 2010, 'Knowledge and beliefs about hiv/aids among male and female students of Nigerian universities', Journal of Comparative Research in Anthropology and Sociology 1(1), 121-131.

Family Health International, 2000, Behavioral surveillance surveys: Guidelines for repeated behavioral surveys in populations at risk of HIV, viewed 31 May 2014 from http://www.who.int/hiv/strategic/en/bss_fhi2000.pdf

Kourtis, A.P., Ibeqbu, C.C., Wiener, J., King, C.C., Tegha, G., Kamwendo, D. et al., 2013, 'Role of intestinal mucosal integrity in HIV transmission to infants through breastfeeding: The BAN study', Journal of Infectious Diseases 208(4), 653-661. $\mathrm{http}: / / \mathrm{dx}$.doi.org/10.1093/infdis/jit221

Long, L.D. \& Ankrah, E.M., 2000, Women's experiences with HIV/AIDS: An internationa perspective, Columbia University Press, New York.

MacLeod-Bluver, C., 2009, I didn't feel like living': the prevalence, perceptions and prevention of HIV/AIDS among Tibetan refugees in Kathmandu, ISP Collection, Paper 807, viewed 31 May 2014, from http://digitalcollections.sit.edu/ isp_collection/807/

Manzardo, C., Treviño, B., Gómez i Prat, J., Cabezos, J., Monquí, E., Clavería, I. et al., 2008, 'Communicable diseases in the immigrant population attended to
in a tropical medicine unit: epidemiological aspects and public health issues', Travel Medicine and Infectious Disease 6(1-2), 4-11. http://dx.doi.org/10.1016/ Travel Medicine and

Mills, E.J., Singh, S., Nelson, B.D. \& Nachega, J.B., 2006, 'The impact of conflict on HIV/ AIDS in sub-Saharan Africa', International Journal of STD \& AIDS 17(11), 713-717. http://dx.doi.org/10.1258/095646206778691077

Molefe, R., 2004, 'Model predicts 380000 AIDS deaths a year by 2010', City Press, 18 July, p. 19.
Ngatu, N.R. \& Kanabara, S., 2014, 'Armed conflict, women's vulnerability and HIV/AIDS in the Great Lake Region of Africa: Reinforcing human security to prevent widespread of the pandemic', Clinical Research in HIV/AIDS 1(1),1003.

Nkwinika, H.E., 2006, 'Refugees' perception of HIV/AIDS in Ba-Phalaborwa municipality', Master's thesis, Graduate School of Leaderships and Management Sciences, University of Limpopo.

Palabora Mining Company Limited, 2012, Ba-Phalaborwa HIV and AIDS statistics, viewed 17 June 2014, from http://www.palabora.com/hiv_aids.asp

Peltzer, K., Vallières, E.F. \& Tabane, C., 2011, 'HIV knowledge, risk perception and risk behaviour among male ex-offenders in Mpumalanga, South Africa', Gender and Behaviour 9(2), 3870-3885

Shisana, O., 2002, South African national HIV prevalence, behavioural risks and mass media - household survey 2002, Human Sciences Research Council, Cape Town.

Slater, M., Stringer, E.M. \& Stringer, J.S., 2010, 'Breastfeeding in HIV-positive women: What can be recommended?', Paediatric Drugs 12(1), 1-9. http://dx.doi. org/10.2165/11316130-000000000-00000

Steele, C.B., Richmond-Reese, V. \& Lomax, S., 2006, 'Racial and ethnic disparities in HIV/AIDS, sexually transmitted diseases, and tuberculosis among women', Journal of Women's Health 15(2), 116-122. http://dx.doi.org/10.1089/jwh.2006.15.116

Tafuri, S., Prato, R., Martinelli, D., Melpignano, L., De Palma, M., Quarto, M. et al., 2010, 'Prevalence of Hepatitis B, C, HIV and syphilis markers among refugees in Bari, Italy', BMC Infectious Diseases 10, 203. http://dx.doi.org/10.1186/ 1471-2334-10-213

Tanaka, Y., Kunii, O., Hatano, T. \& Wakai, S., 2008, 'Knowledge, attitude, and practice (KAP) of HIV prevention and HIV infection risks among Congolese refugees in Tanzania', Health \& Place 14(3), 434-452. http://dx.doi.org/10.1016/ j.healthplace.2007.07.005

The Reader's Digest, 1993, 'Perception', in The Reader's Digest Oxford Complete Wordfinder, The Reader's Digest Association Limited, Cape Town.

Tompkins, M., Smith, L., Jones, K. \& Swindells, S., 2006, 'HIV education needs among Sudanese Immigrants and refugees in the Midwestern United States', AIDs and Behavior 10(3), 319-325. http://dx.doi.org/10.1007/s10461-005-9060-8

UNAIDS (Joint United Nations Programme on HIV/AIDS), 2010, Global report: UNAIDS report on the global AIDS epidemic, viewed 17 July 2014, from http://www. unaids.org/documents/20101123_GlobalReport_em.pdf

UNAIDS (Joint United Nations Programme on HIV/AIDS), 2012, Global report: UNAIDS report on the global AIDS epidemic, WHO Library Cataloguing-in-Publication Data, Geneva.

UNAIDS (Joint United Nations Programme on HIV/AIDS), 2014, Global aids response progress reporting, WHO Library Cataloguing-in-Publication Data, Geneva.

UNHCR (The UN High Commission for Refugees), n.d., Refugees, IDPs \& mobile populations, viewed 17 July 2014, from http://his.unhcr.org/aae/?page_id=367

Van Dyk, A., 2008, HIV/AIDS care and counseling: A multidisciplinary approach, 4th edn., Pearson Education, Cape Town. 